\title{
The Effect of Perceived Quality, Perceived Sacrifice and Perceived Risk on Customers' Perception of Product Value for Electronic Product
}

\author{
Muh. Said ${ }^{1}$, Mustaking ${ }^{2}$ \\ ${ }^{1}$ Sekolah tinggi ilmu Ekonomi (STIE) Nobel Indonesia Makassar. \\ E-mail: muhsaid2601@mail.com \\ ${ }^{2}$ Universitas Puangrimaggalatung, Sengkang. \\ E-mail: takimmuhlab@yahoo.com
}

(Received: February-2020; Reviewed: February-2020; Accepted: March-2020;

Avalaibel Online: March-2020; Published: March-2020)

(7) (\$) This is an open access article distributed under the Creative Commons Attribution License CC-BY-NC-4.0 @2020 by author (https://creativecommons.org/licenses/by-nc/4.0/)

\begin{abstract}
Now days, retailer always make a new marketing strategy to keep their customers needs, so the customer will be satisfied with their product. Customers ' perception for product value usually involving the effect of perceived quality, perceived sacrifice and perceived risk and perceived quality. The objectives of this research was to know whether perceived quality, perceived sacrifice and perceived risk has an effect on customer perception of product value for electronic product. The data were collected from 98 respondents. These respondents has bought electronic product in the previous year. The hypothesized relationship was tested using multiple regression analysis. The analysis showed that country of origin, store name, brand name and price has a positive effect to quality, but price doesn't have a positive effect to perceived sacrifice and also performance risk and perceived risk has a positive effect to financial risk. Another analysis showed that perceived quality doesn't have a negative effect to performance risk and also performance risk and financial doesn't have a negative effect to perceived value.
\end{abstract}

Keywords: Perceived Quality; perceived Sacrifice; perceived Value; perceived risk; Brand; Price.

\section{INTRODUCTION}

Industry era 4.0 Business in the field of electronic development is very fast compared to previous eras, it is characterized by a modern marketing concept where customers can buy online so that the company spends more and more of all market segments in the upper segment competing (M Aras et al., 2018; Muh Aras et al., 2017; Muhammad Aras et al., 2018; Irmal et al., 2020; Selang, 2013). This competition makes consumers more choices this will benefit consumers because they avoid bargaining, if one product is profitable then other consumers will order via online and vice versa. If one product is unsatisfactory, consumers will easily look for other products with acceptable value, not only satisfying, but consumers must be confident 
about the perceived quality of pride (Sunarsi \& Baharuddin, 2019; Yuangga \& Susanti, 2019). Qualiti Perception, Victim Perception, Perception Risk and brand equity will be a factor of added value or value to electronic products. If consumers do not have a good image perception of prouduk brands, then this small customer will return to buy the prouduk brands.

The Perceived Quality according to Aaker \& Joachimsthaler (2000) is the Perceived Quality in which the grill has a perception of the overall quality or excellence of the product or service as expected. The perceived quality is not determined because it is the perception of the customer and between the customer and the sharp differences in their personality, needs and perception. According to Keller \& Lane (2013) that Perception is largely determined by customer satisfaction obtained, while the understanding of customer satisfaction according to Kotler \& Keller (2009) is a feeling of pleasure or satisfaction someone who arises because of improving the performance prepared for their exploitation. If Prouduk is marketed it fails to meet the expectations, then the grill will not be satisfied, if the population is able to meet the expectations then the grill will be satisfied. If the purchased Proudak is able to exceed expectations, the grill will be very satisfied or very happy, the rating of the proud grill depends on the factors of Perception of Quality, Quality, Perception of Sacrifice and Perceved Value. in accordance with the title of the appropriate material.

This consumer perception shows the existence of the Sacrifice Perception factor that ultimately gets customer loyalty, if we want to provide greater value to consumers then of course we must give a greater benefit value compared to consumer sacrifice (Sacrifice Perception). Definition of Sacrifice Perception according to (Murphy et al., 2008), 201 says that it is considered to consist of two dimensions namely the business dimension (business) and the dimension (business), the business dimension is the calculation of money and work is a condition that can be paid. Residents cannot offer the benefits offered. Products that are offered as an unbalanced sacrifice of consumers and are a value for customers for what consumers will be obtained and customers must make sacrifices to what they need in other words the sacrifice that has been provided by consumers to get the product offered is uncertainty and consequences.

Consumers often feel uncertainty in choosing the product to be purchased, consumers feel the mismatch between expectations and encouragement that is influenced by certain situations, consumers feel a risk that cannot meet their desires, consumer risk perceptions differ from other consumers depending on individual product situations and culture. While the high and low levels of risk perceived by risk depend on the perceptions of each consumer of these consequences, if consumers feel a high level of risk while others tend to feel lower risk, so consumers who feel a higher level of risk have the possibility to be more careful careful for the choice of products they will buy, on the other hand a consumer feels a low level of risk will be more daring to bear the consequences of a bad decision of their choice of a particular product. According to (Raspati, 2016), Perceived Risk is a kind of uncertainty that will be faced by consumers when they cannot see the consequences of a purchase decision. The above definition underlines a dimension that is relevant to Perceived Risk, namely uncertainty and consequences. Factors that can increase consumers' perceived risk are caused by the lack of information about the product to be purchased, especially if the product is a new product, another consequence is where consumers do not have the confidence to evaluate the product especially if consumers feel the product is needed because the consumers do not takes a long time to have the product which ultimately consumers get with the consequence of uncertainty as a result the value (Value) obtained by consumers is not felt even though the value has a direct influence on customer satisfaction. 
The Indonesian Perceived Value is Perception of Value, as discussed above is as a benefit to be received compared to costs, Agarwal \& Teas (2001) can also be said that the perception of value is that customers will pay for all services provided but it would be better if what they pay the same as what they feel and they feel the use of valuable money, besides that Perceived value is used by consumers to summarize various aspects of service relationships to profitable deals or it can be concluded that Perceived Value as a calculation of costs and other financial aspects . From the discussion above Perceived Quality, Perceived Sacrifice Perceived Risk and Perceived Value, the other factors influencing the perception of Product Value are Brand, Price, Store Name, or Contry of Origin, and Functional risk.

There have been many studies examining the impact caused by brand names, because brands are a strategic asset and are key in long-term implementation and should be managed well, Keller \& Lane (2013) stated that brands are product names or symbols that distinguish shapes, logo logos, packaging to identify an item or service from a particular seller or group, a Brand is very influential with Price, because a quality brand generally has a higher price than a low quality brand that will limit the company's opportunity to give a high price. Store Name Factors, Store Names have an impact on customers because consumers will be loyal to store names or store name perceptions as a brand and brand is an important factor for the place to develop their business, especially in modern marketing. While the Funcional Risk Factor is a combination of other risk dimensions contained in the appearance of a product or in other words Funcional Risk is the risk felt by a consumer if the product he bought has a value that does not match the amount of money spent.

\section{METHOD}

This research is a hypothesis testing or hypothesis testing that aims to test the hypothesis of independent variables that have an influence on the dependent variable and the dependent variable that is testing the influence of Perceived Quality, Perceived Sacrifere, perceived risk, Perceived Value, Brand, Prece, store Name or Contry of Origin and Functional Risk of Independent Product Value variables for electronic products, partially or simultaneously, the variables used in this study are Perceived Quality, Perceived Sacrifere, perceived risk, Perceived Value, Brand, prce, store Name or ContryOfine and Fungcional Risk variables and variables Product Value. The sample used in this study uses a simple random sampling method in which a procedure that allows each element in the population that has the same opportunity to be sampled. The sample in this study are consumers who have purchased electronic products in the past year.

general characteristics of respondents which in turn will affect electronic purchases marketed in Makassar City and surrounding areas such as the Makassar suburbs; Maros Regency, Gowa Regency Takalar Regency and Jeneponto Regency and will be measured based on Gender, Age, Education, Domicile, Status, Occupation, Purchased Product, Shop where to buy the Product, Made in the Country and the price of the research results can be described in Table 1-11. 
Table 1

Characteristics of Respondents by sex

\begin{tabular}{lcc}
\hline Characteristics & Frequency & $\begin{array}{c}\text { Percentage } \\
(\boldsymbol{\%})\end{array}$ \\
\hline Men & 52 & 53.1 \\
\hline Woman & 46 & 46.9 \\
\hline
\end{tabular}

Data source : data Year 2020

In table 1 above, it appears that the majority of respondents, as many as 52 people are men (53.1\%), while the rest, as many as 46 people are female respondents (46.9\%), this shows that male respondents in this study are more dominant. This composition shows that male respondents are still dominant in making decisions in purchasing electronic products, however, women still influence $46.9 \%$, which means that a $6.2 \%$ difference in women's influence can still influence men's decision making.

Tabel 2

Characteristics of respondents Age

\begin{tabular}{lcc}
\hline \multicolumn{1}{c}{ Age } & Frequency & Percentage $(\boldsymbol{\%})$ \\
\hline$<21$ years old & 3 & 3.0 \\
21-30 years & 77 & 78.5 \\
31-40 years & 11 & 11.2 \\
$>40$ years old & 7 & 7.3 \\
\hline
\end{tabular}

Source of data processing 2020

While based on age group, most respondents. are aged between 21-30 years as many as 77 people (78.5\%), then aged between $31-40$ years as many as 11 people (11.2\%), and for respondents aged over 40 years as many as 7 people (7.3\%), while the lowest is respondents aged under 21 years as many as 3 people, $(3.0 \%)$ this shows that the composition of the productive age of 21-30 years and 31-40 years dominates the purchase of electronic products.

Tabel 3

Karakteristik pendidikan

\begin{tabular}{lcc}
\hline Pendidikan & jumlah & $\%$ \\
\hline High school & 5 & 5.1 \\
\hline Diploma & 36 & 36.7 \\
\hline Graduate (S1) & 26 & 26.5 \\
\hline Undergraduates (S2) & 22 & 22.4 \\
\hline Doctor & 9 & 9.3
\end{tabular}

Source : 2020 data processing 
For the education level, most respondents were educated with a Diploma of 36 people (36.7\%), 26 graduates (S1) (26.5 undergraduate graduates (S2) amounting to 22 people (22.4\%), and 9 doctoral graduates (S3) (9.3\%) while for education with a high school level of 5 people, from the data above it can be seen that the education level of Diploma, Bachelor Degree, Bachelor Degree has economic maturity so that the percentage of purchase of electronic products is dominant in terms of the education level while at S3 level it is estimated that they already have electronic products, whereas for high school graduates it is estimated that the rate of income is unstable.

\section{Table 4}

\section{Status Characteristics}

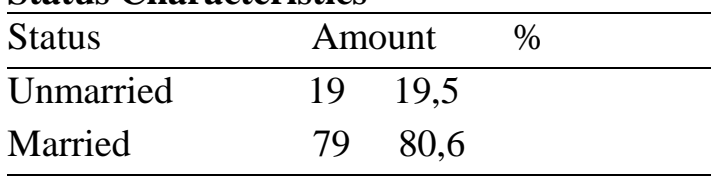

Source of data processing 2020

The majority of the marital status of respondents is unmarried as many as 19 people (19.4\%) and as many as 79 people are married (80.6) electronic needs are really needed for consumers who are married, unmarried consumers still have the opportunity to buy electronic products $(19,4 \%)$

\section{Table 5}

Domicile Characteristics

\begin{tabular}{lcc}
\hline Domicile & amount & $\%$ \\
\hline Makassar city & 37 & 37.8 \\
Maros Regency & 19 & 19.3 \\
Gowa Regency & 18 & 18.4 \\
Takalar Regency & 16 & 16.3 \\
Jeneponto Regency & 8 & 8.2 \\
\hline So
\end{tabular}

Source of data processing 2020

Respondents residing in the city of Makassar were 37 people (37.8\%), in Maros district 19 people (19.3\%), who were domiciled in Gowa district, 18 people (18.4\%), Takalar district were 16 people (16.3\%) and those who were residing in Jeneponto 8 people (8.2\%). From the table illustrates that the most electronic product marketing areas are in the city of Makassar, while electronic marketing in the regency on the outskirts of Makassar shows that sales of electronic products are almost equal except in the Jeneponto district. because the regency of jeneponto is closer to the electronic marketing area in Bantaeng and Bulukumba Regencies. 
Table 6

Job Characteristics

\begin{tabular}{lcc}
\hline Employment & Amount & \% \\
\hline Government employees & 9 & 9.2 \\
Private employees & 24 & 24.5 \\
Entrepreneurs / Traders & 39 & 39.8 \\
Farmers & 18 & 18.3 \\
Daily Labor & 8 & 8.2 \\
\hline
\end{tabular}

Source of data processing 2020

Respondents' jobs are seen as more employed as employees / traders 39 people (39.8\%), private employees with 24 people $(24.5 \%)$, 9 civil servants $(9.2 \%), 18$ farmers $(18.3 \%)$, day laborers 8 people $(8.2 \%)$ see the data, then the work of entrepreneurs has the effect of purchasing electronic products, followed by private employees so that marketing of electronic goods should be directed to those who work as private employees and entrepreneurs / traders, but who work Farmers, day laborers and civil servants are still working on meeting sales targets.

\section{Table 7}

Product Characteristics

\begin{tabular}{lcc}
\hline Product purchased & Amount & \% \\
\hline Audio / Video & 3 & 3.1 \\
Home Appliance & 15 & 15.3 \\
Cellphone & 35 & 35.7 \\
Computer Appliance & 11 & 11.2 \\
Television & 34 & 34.7 \\
\hline
\end{tabular}

Source of data processing 2020

From the questionnaire distributed, obtained product information purchased by respondents for Audio / Video products as many as 3 people (3.1\%), Home Appliance 15 people (15.3\%), Mobile 35, people (35.7\%), Computer Appliance 11 people, $(11.2 \%)$ and television products 34 people $(34.7 \%)$ from the above data Television and Cell Phone sales are still consumers' choices given that those needs are the main needs for information from daily life.

\section{Table 8}

Brand Characteristics

\begin{tabular}{lll}
\hline characteristics & Amount & $\mathbf{( \% )}$ \\
\hline Samsung & 43 & 43.9 \\
Toshiba & 2 & 2.1 \\
Sanken & 9 & 9.2 \\
LG & 24 & 24.4 \\
Polytron & 4 & 4.1 \\
Lainya (Nokia, Akira etc.) & 16 & 16.3 \\
\hline
\end{tabular}

Source of data processing 2020 
The brands of electronic products purchased are very diverse, but the majority of respondents buy LG and Samsung branded products, for the purchase of these products are already attached to the consumer brand image, namely Samsung products 43 people (43.9\%) and LG Products 24 people (24\%) for Toshiba branded electronic products were bought by consumers $2(2.1 \%)$, this is because the products available at the Electronic Store are very limited and whereas the politron brand is only 4 people (4.1\%) and Sanken 9 people (9.2\%) both brands are alternative brands for consumers and for brands such as (Nokia, Akira, Sony, etc.) bought by consumers 16 people (16.3\%) and consumers tend to ignore these brands.

\section{Table 9}

Characteristics of the Store

\begin{tabular}{lcc}
\hline Shop where to buy & Amount & \% \\
\hline Alaska & 26 & 26.5 \\
Columbus & 38 & 38.8 \\
Columbia & 4 & 4,1 \\
Simpatyk & 12 & 12.2 \\
Premium & 11 & 11.2 \\
Other (Carefour, Electronic city & 7 & 7.2 \\
Hypermark) & & \\
\hline
\end{tabular}

Source of data processing 2020

Stores where buying electronic products, notable in the data that bought in Alaska Stores as many as 26 people (26.5\%), Colombus 38 people (38.8\%), Columbia as many as 4 people (4.1\%), Sympatik 12 people (12.2\%), Premium stores 11 people $(11.2 \%)$, while for other stores such as Carefour Citi Hypermart Electronics, there are only 7 people or (7.2\%). From the data above, stores with Cash and Credit status such as Columbus, Columbia, Sympathetic, and peremium are still selected by consumers to buy products electrical engineering, while the Alaska Store is a central Electronic purchasing center with a choice for middle and upper consumers, in other stores (Carefour, Cyti Electronics, Hypermark is a modern store that will be visited by upper market segments.

Table 10

Characteristics of Country-Made Products

\begin{tabular}{lcc}
\hline Country- & made products & \% \\
\hline Korea & 26 & 26.5 \\
Japan & 22 & 22.4 \\
Taiwanese & 11 & 11.2 \\
China & 17 & 17.4 \\
Indonesia & 14 & 14.3 \\
Other (USA-EUROPE) & 8 & 8.2 \\
\hline
\end{tabular}

Source of data processing 2020 
Electronic products purchased with Korean-made products were 26 people (26.5\%), Japan 22 people (22.4\%), Taiwan 11 people (11.2\%), Chinese 15 people (17.4\%), Indonesia 14.3 people (2\%) and from other countries as many as 8 people $(8.2 \%)$. Products made in Korea are still the main choice for consumers, but products made in Japan are still preferred by consumers, but the available products are limited while for the production of Taiwanese products, Chinese Indonesian and European products are alternative choices for consumers.

\section{Table 11}

\section{Price characteristics}

\begin{tabular}{lcc}
\hline Price & Amount & $\%$ \\
\hline$<1 \mathrm{M}$ & 20 & 20.4 \\
$1-3$ million & 50 & 51.0 \\
$>3-5$ million & 15 & 15.3 \\
$>5-10$ million & 8 & 8.2 \\
$>10$ million & 5 & 5.1 \\
\hline
\end{tabular}

Source : 2020 Data Process

For the price of products purchased the majority of respondents bought products with prices between 1-3 million as many as 50 people (51\%), prices below 1 . million as many as 20 people (20.4\%), prices between 3-5 million - as many as 815 people $(15.3 \%)$, prices between 510 million as many as 8 people $(8.2 \%)$ and above 10 million as many as 5 people $(5.1 \%)$ from the data above can be seen by consumers with prices of 5 million to> 10 million is the middle and upper market share. while the analysis tool used is SPSS.

\section{RESULT AND DISCUSSION}

\section{Data analysis}

\section{Data Validity Test}

testing the validity of the data using construct validity analysis using factor analysis. Factor analysis is done by determining each dimension in the question items. The following is the result of a construct validity test (exploratory factor analysis) where construct validity, which includes understanding the theoretical arguments underlying the measurements obtained with the approach carried out, is to link a variable examined with other variables formed from the theoretical framework. The validity testing method in this study uses the anlysis factor. The basis for making a validity test is as follows:

If measure of sampling adequacy (MSA) $\geq 0.50 \rightarrow$ item valid statement If measure of sampling adequacy (MSA) $<0.50 \rightarrow$ item statement is invalid . A summary of the results of validity testing conducted with factor analysis with the help of software is presented in table 12 . 
Table 12

Summary of Construct Validity Testing

\begin{tabular}{lll}
\hline $\begin{array}{c}\text { Variable / Statement } \\
\text { Items }\end{array}$ & $\begin{array}{c}\text { KMO-MSA } \\
\text { Overall }\end{array}$ & Decision \\
\hline Perceived Quality & $0.834(\mathrm{p}=0,000)$ & Valid \\
Perceived Value & $0.761(\mathrm{p}=0,000)$ & Valid \\
Perceived Sacrifice & $0.500(\mathrm{p}=0.000)$ & Valid \\
Brand & $0.593(\mathrm{p}=0.000)$ & Valid \\
Price & $0.577(\mathrm{p}=0.000)$ & Valid \\
Store Name & $0.586(\mathrm{p}=0.000)$ & Valid \\
Country of Origin & $0.804(\mathrm{p}=0,000)$ & Valid \\
Financial Risk & $0.562(\mathrm{p}=0.000)$ & Valid \\
Performance Risk & $0.500(\mathrm{p}=0.000)$ & Valid \\
\hline
\end{tabular}

From table 12 , it appears that all the items in the research instrument can be used with valid reasons based on testing the construct validity with a factor analysis tool or facor analysis. Therefore, all items can be included in subsequent data processing.

\section{Reliability Test}

As stated by Sekaran (2003) $\mathrm{j}$ said that the reliability test is a test of the goodness of data that illustrates the stability and consistency of the measurements, this study uses an inter-item reliability consistency test. The Cronbach Alpha coefficient number of each variable and dimension in the measurements used by this study.

\section{Table 13}

\section{Research Instrument Reliability Test Results}

\begin{tabular}{lcc}
\hline Variables / Dimension & $\begin{array}{c}\text { Number of } \\
\text { items }\end{array}$ & $\begin{array}{c}\text { Cronbach } \\
\text { Alpha Coeff }\end{array}$ \\
\hline Perceived Quality & 5 & 0.963 \\
Perceived Value & 5 & 0831 \\
Perceived Sacrifice & 2 & 0863 \\
Brand & 4 & 0.558 \\
Price & 3 & 0.577 \\
Store Name & 3 & 0.786 \\
Country Name & 6 & 0.993 \\
Financial Risk & 3 & 0703 \\
Performance Risk & 2 & 0868 \\
\hline
\end{tabular}

Based on table 13 , it can be seen that the Cronbach Alpha coefficient on each variable and dimension of this research instrument is reliable because it meets the minimum reliability requirements with the inter-item consistency method in the Cronbach Aplha coefficient range of 0.5 - 0.6 Nunally. 


\section{Descriptive statistics}

This chapter will begin with the results of descriptive statistical processing of the variables observed in this study, then proceed with testing hypotheses. Table 14 below is the result of processing descriptive statistics from the variables of this study.

Table 14

Descriptive statistics

\begin{tabular}{lcccc}
\hline \multicolumn{1}{c}{ Variables } & Minimum & Maximum & The mean & Std. Deviation \\
\hline Perceived Quality & 2.00 & 5.00 & 3.89 & 0.67 \\
Perceived Value & 1.40 & 4.80 & 3.84 & 0.55 \\
Perceived Sacrifice & 1.00 & 5.00 & 2.96 & 1.03 \\
Brand & 1.50 & 4.25 & 3.10 & 0.64 \\
Price & 1.67 & 4.33 & 2.69 & 0.70 \\
Store Name & 2.33 & 5.00 & 3.43 & 0.67 \\
Country of Origin & 2.33 & 5.00 & 3.59 & 0.70 \\
Financial Risk & 1.33 & 4.00 & 2.64 & 0.78 \\
Performance Risk & 2.50 & 5.00 & 3.89 & 0.61 \\
\hline
\end{tabular}

Based on table 3.1. it appears that the distribution of differences in responses to the average response (standard deviation / standard deviation) averaged below 1.00, except perceived sacrifice, answered by respondents with a difference in the distribution of average answers that are relatively heterogeneous.

In the existing variables, it appears that the variables perceived quality, perceived value, brand, store name, country of origin and performance risk have an average number of respondents' answers that are relatively the same, namely in the average range of 3,100 to 3,893 . This means that on the points of the statement of these variables, the average respondent answers neutral (at 5 answer points, where 1 to state strongly disagree to 5 to state strongly agree). However, the variable perceived sacrifice, price, and financial risk have the lowest average answers of respondents, namely the average number of 2,643 to 2,959. By paying attention to the 5 answer points available for the respondent to choose, the average respondent's answer is to disagree but tends to be neutral for the items in the perceiveid sacrifice, price, and financial risk variables .

The lowest average answer value of respondents on several variables is in the number 1 , which indicates the question items on the variable respondents answered at the lowest available choice, namely number 1 as a statement strongly disagree with the items that exist. While the numbers the highest respondent's answer is at 5.00 which indicates that the respondent tends to strongly agree with the statement items contained in these variables. Except the financial risk variable which has the highest number of respondents' answers, which is at 4.00 which means this variable has the lowest number of respondents' answers for the maximum number of respondents' answers. 


\section{Hypothesis test}

Testing of the hypotheses contained in this study that uses multiple regression analysis or multiple regression, including discussion one by one .

Hypothesis Testing \# 1

H0 1: Country of origin, Store Name, Brand Name, and Price do not have a positive effect on Perceived Quality

Subject: Country of origin. Store Name, Brand Name, and Price have a positive effect on Perceived Quality

By using multiple regression analysis to test the above hypothesis, in table 15 the results obtained from the hypothesis testing are reported .

Table 15

Country of Origin (CO), Store Name (SN), Brand Name (BR) and Price (PC) Regression Test Results on Perceived Quality

\begin{tabular}{|c|c|c|c|c|}
\hline Hypothesis & P. & $\mathbf{t}$ & $\operatorname{Adj.} \mathrm{R}^{\mathrm{z}}$ & $\mathbf{F}$ \\
\hline$\overline{\mathrm{CO}}->$ Quality & 0.426 & $5,066 * *$ & \multirow{4}{*}{0.492} & \multirow{4}{*}{$24,490 * *$} \\
\hline BR -> Quality & 0.381 & $4,606 * *$ & & \\
\hline PC -> Quality & -0.160 & $-1.887^{\mathrm{ns}}$ & & \\
\hline SN -> Quality & 0.323 & $3,948 * *$ & & \\
\hline
\end{tabular}

Note: *: significant at $p<0.10$

$* *$ : significant at $p<0.05$

ns: not significant

Table 15 reports the results of multiple regression tests for country of origin, store name, brand name, and price factors as independent variables on perceived quality as the dependent variable, and the adjusted coefficient of determination $\mathrm{R}$ is 0.492 . This shows that the perceived quality variable or perceived quality as the dependent variable can be explained by the country of origin, store name, brand name and price variables as large variables at $49.2 \%$. F- test as a whole test on the regression equation to be tested, shows a figure of 24,490 by considering a significance number below $p$ of $0,000(p<0.05)$, the results obtained that this overall regression equation can be accepted significantly. Thus, this research rejects Hoi and accepts the case where country of origin, store name, brand name and price variables have a significant positive effect on perceived quality. While the results of / -test as a partial test / one by one independent variable on the dependent variable, in table 4.2. it appears that the country of origin, brand name and store name variables have a significant positive effect on perceived quality. While the price factor is not proven to have a positive effect on perceived quality.

The country of origin variable is the variable that has the biggest significant positive influence with a $\mathrm{P}$ of 0.426 to perceived quality with a $\mathrm{t}$ of 5066 (which is significant at $p$ $<0.05)$. While the brand name variable $(\mathrm{P}=0.381)$ and store name have a lower effect $(\mathrm{P}=$ 0.323 ) when compared to the effect that country of origin can have on perceived quality. Slightly different from previous research results that the four variables ( country of origin, brand name, price, and store name) have a significant effect on quality (Agarvval and Teas, 2001). In this study, it can be explained that overall the country of origin, brand name, price and 
store name factors have a positive effect on quality, but if one by one of the four variables is seen, the price factor is not proven to have a positive effect on quality.

This difference can be caused by several things. First, respondents feel that if a product is made by a well-known country, is sold in a store that has a good name, and the brand is wellknown, then their views on the quality of a product will be higher, but in terms of price . if the price is more expensive or cheaper does not make the respondent can judge the quality of a product. Secondly, previous studies compared price levels that are expensive, medium and cheap.

Hypothesis Testing \# 2

H02: Price does not have a positive effect on Perceived Sacrifice

Ha2: Price has a positive effect on Perceived Sacrifice

By using multiple regression analysis to test the hypothesis above, in Table 16 below are reported the results obtained from testing the second hypothesis.

Table 16

Price Regression Test Results (PC) against Perceived Sacrifice

\begin{tabular}{lllll} 
Hypothesis & P. & $\mathbf{t}$ & $\mathbf{R}^{2}$ & $\mathbf{F}$ \\
\hline PC $>$ Sacrifice & 0.15 & $0.151^{\mathrm{ns}}$ & 0,000 & $0.023^{\mathrm{ns}}$ \\
\hline
\end{tabular}

Note: *: significant at $p<0.10$

**: significant at $p<0.05$

ns: not significant

Table 16 reports the results of multiple regression testing for the price variable as the independent variable of perceived sacrifice as the dependent variable, the coefficient of determination / $\mathrm{R}$ "obtained for 0.000 . This shows that the perceived quality variable or the perceived quality as the dependent variable cannot be explained by price.

T-test as a whole test on the regression equation to be tested, shows a figure of 0.023 by considering a significance number below $p$ of 0.880 so that the results of this regression equation as a whole can be unacceptable. Thus, this study is like rejecting Ho2 and unable to accept $\mathrm{Ha} 2$ where the price variable does not have a positive effect on perceived sacrifice .

In contrast to previous research reports (Agarwal and Teas, 2001), this study cannot prove that price has a positive effect on perceived sacrifice because: First, previous studies compared class / price levels, namely cheap, medium, and expensive whereas in this study not and previous research comparing several types of products namely electronics, watches and shoes. The second thing that causes differences in the results of this study with previous research occurs because respondents are still sensitive to the price of a product, so that if the price is higher then the respondent will not dare to sacrifice to buy the product.

\section{Hypothesis Testing \# 3}

Ho3: Perceived Quality has no negative effect on Performance Risk

Ha3: Perceived Quality has a negative effect on Performance Risk

By using multiple regression analysis to test the above hypothesis, in table 17. the following results are reported from the second hypothesis testing . 
Table 17

Test Results of Perceived Quality (PQ) Regression on Performance Risk

\begin{tabular}{ccccc}
\hline Hypothesis & P. & $\mathbf{t}$ & $\mathbf{R}^{\mathbf{2}}$ & $\mathbf{F}$ \\
\hline PQ -> Performance Risk & 0833 & $14777 * *$ & 0.694 & $218,173 * *$ \\
\hline Note: $*$ : significant at $p<0.10$ & & & & \\
$* *$ : significant at $p<0.05$ & & & & \\
ns: not significant & & &
\end{tabular}

Table 17 , illustrates the results of multiple regression testing for variables perceived quality as independent variables on the performance risk as the dependent variable, obtained the coefficient of determination / $\mathrm{R}^{2}$ of 0.691 . This shows that the performance risk variable perceived as the dependent variable can be explained by the perceived quality variable as a large variable of $69.1 \%$. F-test as a whole test on the regression equation to be tested, shows the number 218.173, taking into account the significance number below $p$ of $0.000\{p<0.05)$, the results obtained that this regression equation as a whole can be accepted significantly, but the perceived quality variable becomes variables that have a significant positive effect with $\mathrm{P}$ of 0.833 on performance risk with t of 14,771 (which is significant at $p<0.05$ ). Thus, this study failed to reject $\mathrm{Ho} 3$ and unable to accept Ha3 where the perceived quality variable did not negatively affect performance risk.

This shows that perceived quality does not have a negative influence on consumer perceptions about the performance risk of a product. In contrast to previous research reports (Agarwal and Teas, 2001), this study cannot prove that perceived quality has a negative effect on performance risk because: First, previous studies compared the quality of products not only electronic products but also other products such as shoes and wristwatch.

The second thing that causes differences in the results of this study with previous research occurs, that respondents feel the quality of a product cannot guarantee the performance risk of a product to be reduced even though the quality of the product to be bought is very reliable or very good.

Hypothesis Testing \# 4

H04: Performance risk and perceived sacrifice do not have a positive effect on Financial Risk

Ha4: Performance risk and perceived sacrifice have a positive effect on Financial Risk

Using multiple regression analysis to test the above hypothesis, in table 18 . The following are reported results obtained from hypothesis testing. 
Table 18

Results of Regulations on Performance Risk (PR) and Perceived Sacrifice (PS) on Financial Risk

\begin{tabular}{ccccc}
\hline Hypothesis & P. & T & Adj. R & F \\
\hline PR -> Financial Risk & $-0,488$ & $\mathbf{- 5 , 5 7 9} * *$ & \multirow{2}{*}{0.282} & \multirow{2}{*}{$20,028 * *$} \\
\cline { 1 - 3 } PS -> Financial Risk & 0.344 & $3,931^{* *}$ & & \\
\hline Note & & &
\end{tabular}

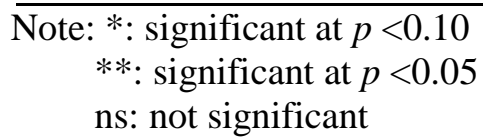

Table 18 reports the results of multiple regression testing for the performance risk and perceived sacrifice variables as independent variables of financial risk as the dependent variable, and the adjusted coefficient of determination $\mathrm{R}^{2}$ is 0.282 . This shows that the perceived quality variable or perceived quality as the dependent variable can be explained by the performance risk and perceived sacrifice variables as large variables at $28.2 \%$. F-test as a whole test on the regression equation to be tested. shows the number 20,028 by considering a significance number below $p$ of $0,000(p<0.05)$, the results obtained that the regression equation as a whole can be accepted significantly. Thus, this study rejects Ho4 and accepts Ha4 where the variable performance risk and perceived sacrifice have a significant positive effect on financial risk.

While the results of the t-test as a partial test / one by one independent variable on the dependent variable, in table 4.5. it appears that the variable perceived sacrifice has a significant positive effect on financial risk, but the performance risk variable becomes a variable that has a significant negative effect with $\mathrm{P}$ of -0.488 to financial risk with $\mathrm{t}$ of -5.579 (which is significant at $\mathrm{p}<0.05)$. The variable perceived sacrifice becomes a variable that has a significant positive influence with a p of 0.344 to financial risk with a t of 3,931 (which is significant at $p<0.05$ ).

Same with previous studies that perceived sacrifice and performance risk have a positive influence on consumers' perceptions of financial risk (Agarwal \& Teas, 2001; AghekyanSimonian et al., 2012; Chakraborty et al., 1996; Chang \& Tseng, 2013; Delgado-Ballester et al., 2014; Kwon \& Noh, 2010). This shows that the respondent feels that the higher the sacrifice to be made, the higher the financial risk that must be faced by the respondent, while the results of the research on performance risk have a negative influence on financial risk, meaning that the respondent does not feel that the product offered is not running as offered does not affect their financial sacrifice due to: (1) The product sold is an electronic product that has a warranty, so that respondents do not have to worry if the product does not run as offered because the respondent. (2) The shop where the respondent buys has a fairly well-known item, so that the respondent is quite sure that the store can be held responsible if the product does not run as offered.

Testing Hypothesis \# 5

H05: Performance risk and Financial Risk do not have a negative effect on Perceived Value Ha5: Performance risk and Financial Risk have a negative effect on Perceived Value

By using multiple regression analysis to test the above hypothesis, in table 4.6. The following are reported results obtained from the first hypothesis testing. 
Table 19

Results of Regression Tests for Performance Risk (PR) and Financial Risk (FR)) against Perceived Value

\begin{tabular}{ccccc}
\hline Hypothesis & P. & T & Ad j. $\mathbf{R}^{\mathbf{2}}$ & F \\
\hline PR $->$ Value & 0.640 & $7,343^{* *}$ & \multirow{2}{*}{0.398} & \multirow{2}{*}{$33,059^{* *}$} \\
\hline FR $->$ Value & -0.002 & $-0,024^{\text {ns }}$ & & \\
\hline
\end{tabular}

\footnotetext{
Note: *: significant at $p<0.10$

**: significant at $p<0.05$

ns: not significant
}

Table 19 reports the results of multiple regression testing for variable performance risk and financial risk as independent variables on the perceived value as the dependent variable, obtained the coefficient of determination that has been adapted / adjusted $\mathrm{R}{ }^{2}$ by 0398 . This shows that the perceived value or quality variable perceived as the dependent variable can be explained by the performance risk and financial risk variables as large variables at $39.8 \%$. Ftest as a whole test on the regression equation to be tested, shows a figure of 33,059 by considering a significance number below $p$ of $0,000(p<0.05)$, the results obtained that this regression equation as a whole can be accepted significantly but the performance risk variable becomes a variable which has a positive effect with $\mathrm{p}$ of 0.640 to the perceived value with $\mathrm{t}$ of 7,343 (which is significant at $p<0.05$ ). While the results of the Mest as a partial test / one by one independent variable on the dependent variable, in table 4.6. it appears that the performance risk variable has a significant positive effect on perceived quality. While financial risk factors have not been proven to have a negative effect on perceived value.

Thus, this study failed to reject $\mathrm{H} 05$ and was unable to accept Ha5 where the performance risk and financial risk variables had a significant negative effect on perceived value. This shows that performance risk does not negatively influence consumers' perceptions of perceived value. In contrast to previous research reports (Agarwal and Teas, 2001), this study cannot prove that performance risk and financial risk negatively affect perceived value because: First, in previous studies comparing performance risk and financial risk not just from one type of product, but from other types of products such as sports shoes, watches and electronic products, the prices are also compared to the level of expensive, medium and cheap.

Second, the results of this study respondents do not feel if the higher performance risk and financial risk it will be able to increasingly influence / reduce respondents' assessment of the value of a product. By paying attention to the overall results of testing the hypotheses contained in this study, the following figure is the test results in a systematic framework.

\section{CONCLUSION}

Based on the results of testing the hypothesis in this study, the conclusions can be drawn that : 1) There is a positive relationship between country of origin, store name, brand name and price on perceived quality. But if you look at one by one of these variables, the price factor is not proven to have a positive effect on quality. 2) As for the price is not proven positive effect on the perceived sacrifice, this is different from previous studies, so it can be seen that the respondents are still very sensitive to changes in the price of a product, if the price the higher the respondents even do not dare to make sacrifices to buy the product $t$ ersebut . 3) From the 
results of this hypothesis it can also be concluded that perceived quality does not negatively affect performance risk, which indicates that respondents feel the good quality of a product cannot guarantee the reduced performance risk for that product. 4) The results of this hypothesis also conclude that overall performance risk and perceived risk have a positive effect on financial risk, so that respondents feel the higher the performance risk and the perceived risk can further increase the influence on their financial condition. And the last result of this hypothesis draws the conclusion that performance risk and financial risk are not proven to have a negative effect on perceived value.

\section{REFERENCES}

Aaker, D. A., \& Joachimsthaler, E. (2000). Brand Leadership: Building Asset in the Information Society. New York, NY: Free Press.

Agarwal, S., \& Teas, R. K. (2001). Perceived value: mediating role of perceived risk. Journal of Marketing Theory and Practice, 9(4), 1-14.

Aghekyan-Simonian, M., Forsythe, S., Kwon, W. S., \& Chattaraman, V. (2012). The role of product brand image and online store image on perceived risks and online purchase intentions for apparel. Journal of Retailing and Consumer Services, 19(3), 325-331.

Aras, M., Jasruddin, J., Akib, H., \& Syam, H. (2018). Marketing Mix Study at Hero Tailor. IOSR Journal of Business and Management (IOSR-JBM), 20(4), 45-51.

Aras, M., Syam, H., Haris, H., Jasruddin, M., \& Akib, H. (2018). The Analysis of Mix Marketing System Toward The Perfomance of Convection Business in Makassar. 1st International Conference on Social Sciences (ICSS 2018).

Aras, M., Syam, H., Jasruddin, J., Akib, H., \& Haris, H. (2017). The effect of service marketing mix on consumer decision making. International Conference on Education, Science, Art and Technology, 108-112.

Chakraborty, G., Allred, A. T., \& Bristol, T. (1996). Exploring Consumers' Evaluations of Counterfeits: The Roles of Country of Origin and Ethnocentrism. Advances in Consumer Research, 23(1).

Chang, E.-C., \& Tseng, Y.-F. (2013). Research note: E-store image, perceived value and perceived risk. Journal of Business Research, 66(7), 864-870.

Delgado-Ballester, E., Hernandez-Espallardo, M., \& Rodriguez-Orejuela, A. (2014). Store image influences in consumers' perceptions of store brands: the moderating role of value consciousness. European Journal of Marketing.

Irmal, I., Gustiarani, E., \& Sunarsi, D. (2020). Pengaruh E-Marketing dan E-Loyality Pengunjung Situs Website www.cankirbogor.com. Jurnal Ekonomi Efektif, 2(2).

Keller, K., \& Lane, K. (2013). Marketing Management. New Jersey: Prentice Hall.

Kotler, P., \& Keller, K. L. (2009). Manajemen pemasaran Jilid 1. In Jakarta.

Kwon, W.-S., \& Noh, M. (2010). The influence of prior experience and age on mature consumers' perceptions and intentions of internet apparel shopping. Journal of Fashion 
Marketing and Management, 14(3), 335-349.

Murphy, L., Schwartz, T. A., Helmick, C. G., Renner, J. B., Tudor, G., Koch, G., Dragomir, A., Kalsbeek, W. D., Luta, G., \& Jordan, J. M. (2008). Lifetime risk of symptomatic knee osteoarthritis. Arthritis Care \& Research: Official Journal of the American College of Rheumatology, 59(9), 1207-1213.

Raspati, F. S. (2016). Prosedur penyediaan dan pemesanan pita cukai hasil tembakau melalui sistem aplikasi cukai-sentralisasi (sac-s) di kantor pengawasan dan pelayanan bea dan cukai tipe madya pabean b Surakarta.

Selang, C. A. (2013). Bauran Pemasaran (Marketing Mix) Pengaruhnya Terhadap Loyalitas Konsumen Pada Fresh Mart Bahu Mall Manado. Jurnal EMBA.

Sunarsi, D., \& Baharuddin, A. (2019). The Effect of Service Quality and Price Accuracy on Consumer Confidence and Implications for Sales Increase. PINISI Discretion Review, $3(2), 101-110$.

Yuangga, K. D., \& Susanti, N. (2019). The Influence of Embeddedness of Socio-Economic Status and Self-Control on Consumptive Behavior of Students (at MA Khazanah Kebajikan Ciputat). PINISI Discretion Review, 3(1), 103-110. 
$242 \mid$ Pinisi Discretion Review

Volume 3, Issue 2, March, 2020 Page. 225- 242 